\title{
6
}

\section{The new order: Australia's perspective on Commonwealth engagement with South-East Asia and the South Pacific, 1946-50}

\begin{abstract}
By study of Pacific affairs, and through expansion of direct diplomatic and consular representation, Australia is setting out to make its own assessments of the problems of the Pacific. By so doing we may speak with a fresh, direct and independent voice in the councils of Pacific nations. It is our wish and intention to play a dynamic part in achieving, as a member of the British Commonwealth, a world comity. It is our destiny and duty to play that part in the Pacific. ${ }^{1}$
\end{abstract}

- Australian Minister for External Affairs, H.V. Evatt

The experiences of World War II, coupled with sweeping changes to the colonial order, reaffirmed the perception of Australia as an outpost of white Western civilisation situated in a dangerous neighbourhood and demonstrated the nation could not rely on the resident order to adequately manage the arc of islands to its north. Australia's postwar foreign policy was accordingly directed towards establishing a regional system in which the area to its north would become a 'self-reliant and 
co-operative [group of] Western Pacific states'. ${ }^{2}$ The roots of this system, it will be recalled, dated back to reports in 1943 compiled by William D. Forsyth of the Pacific Division of the DEA. As this chapter will detail, this system was an integrated one designed to expand Australia's economic, diplomatic and defensive capabilities.

While Canberra sought to implement policies focused on region-specific goals, it continued to require strategic allies. The Chifley government accordingly pursued a cooperative security arrangement with the British Commonwealth and, to the extent possible, the US. This arrangement would be based on the principle of reciprocity, with shared access to strategic bases, intelligence and defence technology. Australia's visions for a cooperative Commonwealth-US security arrangement were complicated by emerging Cold War tensions. Britain and the US believed the Union of Soviet Socialist Republics (USSR) was the most immediate threat and accordingly gave strategic priority to Europe and the Middle East. Australia, conversely, prioritised South-East Asia and the South Pacific and remained reluctant to be coopted into a bipolar view of international affairs. Of particular concern to Australia was the management of the Allied occupation of Japan. The US planned to use the nation as a tool in the Cold War, which stoked Australian insecurity. The Asian nationalist movement-particularly the independence of India in 1947-also complicated Australian defence planning and raised questions about the future role of the Commonwealth.

Faced with this reality, the Chifley government had to find new ways to promote a regional system that was conducive to its national interest. The primary method adopted was a commitment to regional leadership. Contemporary political opponents of the Chifley government and historians since have suggested the government's foreign policy weakened the Commonwealth link in favour of liberal internationalism and assertive regionalism. ${ }^{3}$ There were serious differences between the Australian and British governments-most notably, Australia's support for Indonesian independence and the outright refusal to support the anti-communist

2 “Regional Arrangements with Special Reference to Pacific Policy", DEA Report for 1944 Commonwealth Prime Ministers' Conference, 27 March 1944', in Department of External Affairs: Correspondence files, multiple number series with year prefix [Main correspondence files series of the agency], 1914-93, NAA: A1838, 277/2 Part 1.

3 There are many works on the Chifley government's foreign policy and its legacies. A recent example is Adam Hughes Henry, The Gatekeepers of Australian Foreign Policy (Melbourne: Australian Scholarly Publishing, 2015), 1-7. 
Western Union Defence Organisation. ${ }^{4}$ However, the tendency to focus on points of Anglo-Australian conflict during the Chifley years downplays the degree of similarity and cooperation that still existed in the AngloAustralian relationship.

This chapter argues that the Commonwealth became the primary vehicle for Australia's regional policy in the years 1946 to 1950. Australia prioritised the Commonwealth's presence in the Asia-Pacific region. Along with a defensive presence, Australia encouraged a Commonwealth economic and diplomatic presence by way of investment in the economic development of the South Pacific and, in particular, South-East Asia. While some like David Lee and David Lowe have briefly noted the link between the Colombo Plan and the British commercial crisis throughout 1940, there has been no dedicated study of South-East Asian economic development in relation to the Commonwealth. This chapter explores regional engagement as informed by a broader strategy directed towards strengthening the British world system and developing Australia's longterm diplomatic, economic and strategic capabilities. ${ }^{5}$

Robert Menzies' Coalition government, elected in December 1949, is often presented as the antithesis of the Chifley government. It was seemingly left up to Menzies to steer Australia back towards more balanced relations with Britain and the US, forgoing, for better or worse, internationalism, independence and regional relations. ${ }^{6}$ Conversely, this chapter considers how ideas established by the Chifley government went on to inform the Menzies government's concept of the Commonwealth and Australia's immediate region. An examination of the Colombo Plan for Cooperative Economic Development in South and South-East Asia reveals that the spread of the Cold War into Asia created an opportunity for Commonwealth-US cooperation that was conducive to Australia's plans for regional engagement.

4 Neville Meaney, 'Australia, the Great Powers and the Coming of the Cold War', Australian Journal of Politics and History 38, no. 6 (1992): 316-33, at pp. 316-18, 322-6; Peter Edwards and Gregory Pemberton, Crises and Commitments: The Politics and Diplomacy of Australia's Involvement in Southeast Asian Conflicts 1948-1965 (Sydney: Allen \& Unwin, 1992), 4, 9-11, 17-18, 29.

5 David Lee and David Lowe both briefly note the link between the Colombo Plan and the British commercial crisis throughout the 1940s. David Lowe, 'Percy Spender and the Colombo Plan 1950', Australian Journal of Politics and History 40, no. 2 (1990): 162-76, at p. 164; David Lee, 'Protecting the Sterling Area: The Chifley Government's Response to Multilateralism 1945-9', Australian Journal of Politics 25 (1990): 178-95, at p. 185.

6 For an overview of works pitching the Chifley and Menzies governments' foreign policies against one another, see David McLean, 'Australia in the Cold War: A Historiographical Review', The International History Review 23, no. 2 (2001): 299-321, at pp. 229-301, 304-11. 


\section{The South Pacific Commission: Australia's commitment to regional leadership}

In the 1944 ANZAC Agreement, Evatt made clear that Australia was a Principal Power. When World War II ended, the Chifley government set out to build an institutional framework within which to engage with its region, the centrepiece of which was the South Seas Regional Commission (later renamed the South Pacific Commission, SPC), helped along with enabling institutions like The Australian National University's School of Pacific Studies and an increasing interest in Asian languages in the Australian Public Service. ${ }^{7}$ While the SPC was Australias first significant foray into regional institution building - it is, in fact, still in force today under the new name of the Pacific Community — and despite the sizeable collection relating to the SPC housed at the National Library of Australia, very little has been written on its historical significance. ${ }^{8}$ This is an unfortunate omission from the historical record, for the SPC was developed at a critical juncture in Australia's conceptualisation of the Pacific and its role there.

Originally proposed in the ANZAC Agreement and formalised in February 1947, the SPC was a cooperative regional body formed to study and guide administrative, economic and social development in the South Pacific trust territories. The SPC was in line with the development objectives of the UN Trusteeship Council, which was established in 1945 as one of the foundational bodies of the UN and oversaw trusteeship administration and the gradual move towards self-determination. While the SPC was promoted as strictly separate from political matters, there were, of course, political implications, not the least of which included regional security. ${ }^{9}$ The SPC rested on the idea that economic and social discord in the 'backward' trust territories posed a threat to regional security. For the sake of peace, living standards had to be improved according to Western

\footnotetext{
7 Wayne Reynolds, 'Beyond White Australia: Australian Education and the Engagement of Asia After the Second World War', International Journal of Learning 13, no. 3 (2006): 7-14, at pp. 8-9.

8 Details of this collection can be found in National Library of Australia, 'South Pacific Commission' (Canberra: NLA, 2008 [revised 2019]), available from: www.nla.gov.au/selected-library-collections/ south-pacific-commission.

9 Gregory E. Fry, 'The Politics of South Pacific Regional Cooperation', in The South Pacific: Problems, Issues and Prospects, ed. Ramesh Thakur (London: Palgrave Macmillan, 1991), 171-3; "'A New World in the South Pacific", DEA Report, South Seas Commission Conference, 13 February 1947', in Australian Mission, Political Representative to Allied Forces, Netherlands East Indies [Batavia], Correspondence files, multiple number series [first system, Djakarta/Jakarta] [Main correspondence files series of the agency], 1946-50, NAA: A4355, 17/1.
} 
values. Paternalism and practical limitations aside-namely, uncertainty surrounding future projects being, as it was, an advisory body-the SPC was significant in terms of breaking down Australia's isolation from its region and it went on to shape the nation's involvement with more authoritative bodies such as the UN Educational, Scientific and Cultural Organization (UNESCO) and the UN Economic and Social Commission for Asia (ECOSOC). ${ }^{10}$

The SPC was also an important instrument in Australia's attempt to revive the Commonwealth's presence in the Pacific. ${ }^{11}$ Britain's material and symbolic power was seriously depleted in the course of the war, yet it still had significant colonial responsibilities and commercial and military interests in the Asia-Pacific region. If Britain wished to have an enduring and legitimate role in the region, it was important it acted quickly to stake its claim there. As detailed in the previous chapter, John Curtin's Fourth Empire proposal sought to redefine the role of the Commonwealth, with a focus on engaging with its disparate parts and developing specialist area knowledge as the basis of policymaking. Although Curtin's proposal was not adopted, it can be seen that the Chifley government continued promoting his ideas through the SPC. This argument is supported by discussions during the 1946 Commonwealth Prime Ministers' Conference. British Secretary of State for Foreign Affairs Ernest Bevin described Commonwealth influence in the Pacific as 'somewhat strung out'. He went on to describe his hopes that Britain, India and the Pacific dominions would cooperate in developing a new regional organisation 'built up to provide a binding link between the different parts of the Empire'. Bevin was particularly interested in economic development-a theme on which Evatt quickly capitalised. Evatt noted the Australian-New Zealand idea for the SPC and requested it be included in future plans for a Commonwealth regional organisation, to which Bevin agreed. ${ }^{12}$ This request by Evatt ultimately led to the 1947 South Seas Conference in Canberra at which the SPC was formalised.

10 For discussion of these agencies, see Peter Carroll, 'Australia, ECOSOC and the UN Specialised Agencies', in Australia and the United Nations, eds James Cotton and David Lee (Canberra: Longueville Books with the Department of Foreign Affairs and Trade, 2012), 147-83.

11 Gregory E. Fry, 'International Cooperation in the South Pacific: From Regional Integration to Collective Diplomacy', in The Political Economy of Regional Cooperation: Comparative Case Studies, ed. W. Andrew Axline (London: Pinter Publishers, 1994), 136, 141; Fry, 'The Politics of South Pacific Regional Cooperation', 172-3.

12 'Doc. 206, Minutes First Meeting of Prime Ministers, 23 April 1946', in W.J. Hudson and Wendy Way (eds), Documents on Australian Foreign Policy 1937-49. Volume 9: January-June 1946 (Canberra: AGPS, 1991) [hereinafter DAFP, vol. 9]. 
The SPC was not strictly a Commonwealth organisation, as the US, France and the Netherlands all had interests in the area and joined the commission. Importantly, however, it was an Australian-New Zealand and, by association, Commonwealth initiative. Journalists and policymakers alike accordingly gave emphasis to the link between the SPC and the Commonwealth's enduring presence in the region. Sydney's The Sun newspaper, for instance, described the SPC as an 'Empire scheme', reporting that the 'approval of this scheme means that all the major portions of the Canberra Pact [ANZAC Agreement] have now been adopted as Empire policy in the South Pacific'. ${ }^{13}$ This emphasis on a coordinated Commonwealth policy reflects the weight Australian commentators and the government gave to both the Commonwealth foreign policy framework and Britain's continued presence in this part of the world. Interestingly, the Commonwealth countries had the largest territorial interests and dependent populations in the area covered by the SPC. As a result, Britain, Australia and New Zealand agreed to finance 60 per cent of the commission's budget - the largest contribution. ${ }^{14}$ Conceivably, there was a certain level of prestige attached to this sizeable contribution, signalling the Commonwealth's enduring investment and influence in the region.

Here, it is interesting to briefly note a parallel between the contemporary 'Pacific Step-up' and the SPC. The flagship initiative of the Pacific Stepup is the Australian Infrastructure Financing Facility for the Pacific (AIFFP), a $\$ 2$ billion infrastructure development fund that 'upholds robust standards, avoids unsustainable debt burdens and targets the needs of nations in the region-as identified by them-and unlocks the potential of private sector investment in the region'. ${ }^{15}$ This is expressly in response to the inroads made by China in its vast infrastructure program, the Belt and Road Initiative. Not only will the AIFFP theoretically contribute to sustained growth in the Pacific, increasing the likelihood of economic partnerships, but also it aims to maintain the resident rules-based order that has served Australia's interests. This is alluded to in the joint statement made by then Minister for Trade, Tourism and

13 '“New Empire Scheme Will Develop Pacific Islands", The Sun, [Sydney], 4 May 1946', cutting in Prime Minister's Department: Correspondence files, multiple number series with alphabetical prefix, 1899-1983, NAA: A518, AM815/1/1/A Part 1.

14 “'A New World in the South Pacific", 13 February 1947', NAA: A4355, 17/1.

15 'Realising the Pacific's vision for stability, security and prosperity', Speech, Ewen McDonald, Head of the Office of the Pacific, Canberra, 7 June 2019, available from: www.dfat.gov.au/news/ speeches/Pages/realising-the-pacifics-vision-for-stability-security-and-prosperity. 
Investment Simon Birmingham and Minister for Foreign Affairs Marise Payne: 'We want to remain an enabler of economic opportunity for our neighbours and work with them to build a Pacific region that is secure strategically, stable economically and sovereign politically.' ${ }^{16}$ Where the SPC sought to institutionalise a distinct postwar role for Australia as an engaged and committed neighbour who could be looked to for support in regional development, today, the Pacific Step-up seeks to reaffirm Australia's status as the partner of choice. As we reflect on these parallels, it is important to interrogate the harmful and paternalistic ideas that underpinned Australia's engagement with the Pacific in the 1940s. It is promising, then, to observe the Pacific Step-up's claim to prioritise resilience, sovereignty and sustained partnerships.

\section{Defending Australia}

Prominent voices have dismissed the enduring influence of the ANZAC Agreement and the Fourth Empire, with Joanne Wallis, for instance, writing of the agreement that, after the war, 'Australia began stepping away from the ... plan that Australia and New Zealand would establish a regional zone of defence'. ${ }^{17}$ In reality, as Lee argues, the Chifley government's defence policy 'took up where Curtin left off' ${ }^{18}$ The Chifley government's commitment to greater regional responsibility and encouraging economic, political and social stability in the South Pacific was in concert with defence plans. Australia's postwar regional defence planning was premised on the control of the arc of islands to its north to defend against long and mid-range attacks. The Australian government was eager to see this island defence perimeter incorporated into a broader cooperative regional defence arrangement. During the war, the US had indicated its intention to retain access rights to all the Pacific bases it had built during the war-including Australia's trust territory of

16 'Enhancing Australia's role in Pacific infrastructure projects', Joint media release, Senator the Hon. Marise Payne, Minister for Foreign Affairs, Canberra, 4 April 2019, available from: www.foreign minister.gov.au/minister/marise-payne/media-release/enhancing-australias-role-pacific-infrastructureprojects.

17 Joanne Wallis, Pacific Power? Australia's Strategy in the Pacific Islands (Melbourne: Melbourne University Press, 2017), 35.

18 David Lee, 'Britain and Australia's Defence Policy, 1945-49', War and Society 13, no. 1 (1995): $61-80$, at p. 61 . 
Manus Island. ${ }^{19}$ On 13 March 1946, Minister for External Affairs H.V. Evatt announced to the House of Representatives that, while Australia welcomed the US using the Manus Island base, it would do so only on the basis of reciprocity and a Commonwealth-US 'overall defence arrangement'. ${ }^{20}$ The British shared a similar vision, with Prime Minister Winston Churchill calling for a 'fraternal association' of the British Commonwealth and the US built on an 'intimate relationship between our military advisers, leading to common study of potential dangers, the similarity of weapons and manuals of instructions'. ${ }^{21}$

The foundation of the proposed joint Commonwealth-US arrangement was laid out at the 1946 Prime Ministers' Conference. The attendees agreed there was a need for a revised machinery for Commonwealth defence. This included greater inter-Commonwealth consultation in high-level strategic planning, the regionalisation of defence and each dominion taking on greater responsibility for local defence within its individual region..$^{22}$ It was also acknowledged that, in the future, the Commonwealth would have to work more closely with the US on issues of defence and foreign affairs. The Australian representatives pressed for the necessary next steps to be taken in formalising defence arrangements. Evatt and Chifley tabled the United States' recent request for access to Commonwealth bases in the Pacific, suggesting such access be granted in exchange for a Commonwealth-US 'common defence policy', which included reciprocal base use and certain 'defence obligations'. ${ }^{23}$ The representatives agreed to a united Commonwealth (in this case, Australian, British and New Zealand) response to the US request that would be directed towards the establishment of a cooperative regional security arrangement 'for the maintenance ... of international peace and security in the South Pacific and South-West Pacific areas'. ${ }^{24}$ In the coming

19 Norman Harper, A Great and Powerful Friend: Australia and the United States, 1900-1975 (Brisbane: University of Queensland Press, 1986), 151.

20 CPD: Representatives, 13 March 1946, vol. 186, 200-1.

21 Winston Churchill, 'Sinews of peace', Speech, Westminster College, Fulton, Missouri, 5 March 1946 (Fulton, MO: National Churchill Museum, 2021), available from: www.nationalchurchill museum.org/sinews-of-peace-iron-curtain-speech.html.

22 'Doc. 208, Minutes Third Meeting of Prime Ministers, 24 April 1946' and 'Doc. 210, Minutes Fourth Meeting of Prime Ministers, 25 April 1946', both in Hudson and Way, DAFP, vol. 9.

23 'Doc. 206, Minutes First Meeting of Prime Ministers, 23 April 1946' and 'Doc. 208, Minutes Third Meeting of Prime Ministers, 24 April 1946', both in Hudson and Way, DAFP, vol. 9.

24 'Doc. 213, Minutes Fifth Meeting of Prime Ministers, 26 April 1946', in Hudson and Way, $D A F P$, vol. 9. 
months, both Evatt and Chifley made repeated attempts to negotiate with the US State Department for reciprocal base use and a cooperative regional security arrangement.

Despite initially promising prospects for a Commonwealth-US security arrangement, these hopes were soon dashed. The US made paltry offers for reciprocal access to distant and strategically insignificant bases and doggedly refused to make specific defence commitments in the Pacific. ${ }^{25}$ By mid-1947, the US government informed Australia that its 'strategic interests had already moved north'. ${ }^{26}$ The declining strategic significance of South-East Asia and the South Pacific was largely the result of increasing US-USSR tensions and new plans for the occupation of Japan. Any opportunity for cooperation in nuclear developments was also blocked, with the administration of Harry S. Truman determining the US alone would control and manage the nuclear technology developed by the Manhattan Project. ${ }^{27}$

\section{Regional concepts and the future of Japan}

The foundations of Australia's machinery for regional defence and engagement were being established as US plans for the management of Japan began evolving. The occupation of Japan was managed by two key bodies. The first was the Far Eastern Commission in Washington, which determined the broad policies guiding the occupation of Japan. The second body was the Allied Council for Japan (ACJ) in Tokyo, which advised on the implementation of Far Eastern Commission policies and worked towards peace negotiations. The Supreme Commander of the Allied Council for Japan (SCAP) was US General Douglas MacArthur, with whom the interim administrative directives rested. This system afforded MacArthur a fair amount of flexibility in decision-making and the Australian government had initially hoped it could appeal to him

25 'Doc. 1, Evatt to Chifley', 'Doc. 30, Evatt to Chifley, 19 July 1946' and 'Doc. 316, United States Embassy in Canberra to DEA, 12 December 1946', all in W.J. Hudson and Wendy Way (eds), Documents on Australian Foreign Policy 1937-49. Volume 10: July-December 1946 (Canberra: AGPS, 1993) [hereinafter DAFP, vol. 10]; 'Acheson (Under Secretary of State) to US Embassy in Canberra, 9 December 1946' and 'Memorandum by US Admiral Denfeld, [n.d. (June 1947)]', both in NAA: A6494, SPTS $1 / 1$.

26 'Forsyth Interview', NLA: TRC 121/27, Folder 2/2/151.

27 This decision was formalised in the Atomic Energy Act of 1946. Wayne Reynolds, 'Imperial Defence After 1945', in Australia and the End of Empires: The Impact of Decolonisation on Australia's Near North, 1945-65, ed. David Lowe (Geelong, Vic.: Deakin University Press, 1996), 121-4. 
to ensure Australia played a leading role in the management of Japan. ${ }^{28}$ Australia's William Macmahon Ball was appointed the Commonwealth representative on the ACJ, and the joint British Commonwealth Occupation Force in Japan was commanded by an Australian lieutenant general. These appointments, Macmahon Ball reflected, 'showed a new and interesting development in British Commonwealth relations'. ${ }^{29}$

The occupation of Japan initially operated on the basis of gradual economic reform, with strict controls to limit the nation's war potential. ${ }^{30}$ Generally, this met Australia's desire for an occupation and peace treaty that would provide for the 'complete elimination of Japanese imperialistic militarism'. ${ }^{31}$ From mid-1947, however, the US government began to 'Reverse Course': the promotion of economic rehabilitation through the revival and expansion of capitalism to encourage the economic and social conditions in which democracy could take hold. ${ }^{32}$ The Reverse Course reflected the recent announcement by the USSR and China that they would no longer cooperate with the ACJ, granting the US near free rein in the management of the Japanese occupation and the opportunity to implement the burgeoning Truman Doctrine, which aimed to contain communism by helping certain vulnerable nations maintain their political and economic integrity. Occupied Japan was conducting very little regional trade, with many Asia-Pacific nations still resentful of Japan's recent belligerence. Japan accordingly relied on exports from the US, contributing to a growing dollar deficit and, in turn, susceptibility to economic and political collapse. In supporting Japan's economic development, the US hoped to establish the nation as an industrial hub for East Asia and an economic and strategic bulwark against communism. ${ }^{33}$

Important signifiers of Washington's evolving ideas for Japan and the foundation of US power in Asia include two visits made by US Under Secretary of the Army William Draper-the first in September 1947 and

28 Ai Kobayashi, W. Macmahon Ball: Politics for the People (Melbourne: Australian Scholarly Publishing, 2013), 82-9; W. Macmahon Ball, Japan: Enemy or Ally? (Melbourne: Cassell \& Company, 1948), 21-2.

29 Macmahon Ball, Japan, 29.

30 Michael Schaller, The American Occupation of Japan: The Origins of the Cold War in Asia (Oxford, UK: Oxford University Press, 1985), 65-72.

31 "Security in the Pacific", Address by H.V. Evatt to the Herald Tribune Forum, New York, 2 October 1945', in H.V. Evatt, Australia in World Affairs (Sydney: Angus \& Robertson, 1946), 76.

32 Schaller, The American Occupation of Japan, 78-81; Macmahon Ball, Japan, 196-7.

33 Schaller, The American Occupation of Japan, 24-6, 82-3; 'Attachment, Speech by Royall (Secretary of the Army), 17 January 1948, Eckersley (Acting Head of Australian Mission in Tokyo) to Burton (DEA Secretary), 9 February 1948', NAA: A1838, 3103/11/161 Part 1. 
the second in March-April 1948. Draper, who reportedly opposed heavy reparations and punitive peace, was joined by a retinue of prominent US businessmen charged with examining economic opportunities in Japan and the resources necessary to continue developing them. ${ }^{34}$ Following the trips, the Army Department compiled a list of preliminary recommendations, including greater freedom of movement for Japanese businessmen, restoring power to the Japanese government and a revolving trade fund. The list of recommendations was presented to the State Department, which gave its 'unqualified support' to the rehabilitation of Japan and all associated funding. ${ }^{35}$ This approach to the occupation of Japan was formalised in the National Security Council (NSC) policy paper 13/2, signed on 7 October 1948. NSC 13/2 planned for recovery driven by regional economic integration, arrangements for Japanese military security and the signing of a lenient peace treaty. ${ }^{36}$ At this point, the State Department seized control of initiatives in Japan, MacArthur lost much of his administrative power and any opportunity for Australia to influence SCAP decision-making virtually disappeared.

The US considered Australia's endorsement of its policy towards Japan 'highly desirable' because of its role in the ACJ and membership of the Commonwealth, in which Australian support could 'usually be counted upon to involve New Zealand and often UK support'. ${ }^{37}$ While Australian policymakers agreed that a stable Japanese economy was necessary for lasting peace, they feared the Reverse Course would place Japan 'in a position where her industries are built up to constitute a war potential'. ${ }^{38}$ Patrick Shaw, the Commonwealth representative on the ACJ following Macmahon Ball's departure, was concerned by the thinly veiled justifications for the new US approach:

34 “"The Trend of United States Policy Towards Japan”, [n.d. (April 1948)]' and 'Australian Mission in Tokyo to DEA, 31 March 1948', both in NAA: A1838, 3103/11/161 Part 1.

35 John Stenson-Wright, Unequal Allies? United States Security and Alliance Policy Towards Japan, 1945-60 (Stanford, CA: Stanford University Press, 2005), 32-4; Schaller, The American Occupation of Japan, 122, 131-7; 'Doc. 651, Royall to Acting Secretary of State, 23 April 1948', in John G. Reid and David H. Stauffer (eds), Foreign Relations of the United States, 1948, The Far East and Australasia, Volume VI (Washington, DC: US Government Printing Office, 1974) [hereinafter FRUS 1948].

36 'Doc. 588, Attachment, "Recommendations with Respect to United States Policy toward Japan", Report by the NSC, 7 October 1948', in Reid and Stauffer, FRUS 1948.

37 'Doc. 1, Policy Statement of Department of State, 18 August 1948', in Reid and Glennon, FRUS 1949.

38 “"The Trend of United States Policy Towards Japan”, [n.d. (April 1948)]', NAA: A1838, 3103/11/161 Part 1. Evatt reiterated these concerns in an address to Parliament, arguing that 'it will be an evil day for Australia if Japan is given capacity to rearm'. CDP: Representatives, 8 April 1948, No. 15, 747. 
The most frightening aspect of the present development of American policy is that while it is ostensibly aimed at 'lightening the burden of Occupation on the American taxpayer', everyone including the Japanese, knows the aim is the re-establishment of a strong Japan as the bulwark against the USSR. Strength implies military as well as economic revival. ${ }^{39}$

The Australian government was also concerned by America's concept of the Asia-Pacific region. Japanese economic rehabilitation relied on treating the Pacific and South-East Asia as a 'Japanese quarry', from which raw materials could be sourced, converted into manufactured goods and sold back to these same regional nations. ${ }^{40}$ This arrangement undermined plans for a self-reliant regional system and relegated its immediate area of strategic concern to merely an appendage of US policy. Australia accordingly rejected US plans for Japan, promoting a just yet disciplinary peace treaty 'in which all participants in War had full voices'. ${ }^{41}$ In the ACJ, Shaw doggedly resisted US attempts to relax restrictions on Japanese travel and commercial fishing. ${ }^{42}$ The Chifley government's position, along with its reluctance to accept the Cold War world view, made for frigid Australian-US relations throughout the immediate postwar years. ${ }^{43}$

Australia's response to America's unacceptable concept for Asia-Pacific security was to promote a Commonwealth solution. The Chifley government acted quickly to coordinate new security arrangements with Britain. The Anglo-Australian Joint Project was established in 1946, leading to the development of the Woomera Range Complex in South Australia, where long-range missiles were to be tested. ${ }^{44}$ As previously noted, at the 1946 Prime Ministers' Conference, it had been agreed that Commonwealth defence planning would be revised with a view to organising on a regional basis, although no definite machinery was established. In early 1947, Australia took preliminary steps towards

39 'Shaw to DEA, 24 March 1948', NAA: A1838, 3103/11/161 Part 1.

40 Reynolds, 'Imperial Defence After 1945', 125.

41 “"The Trend of United States Policy Towards Japan”, [n.d. (April 1948)]', NAA: A1838, 3103/11/161 Part 1; 'Attachment, Evatt Address to ECOSOC, 30 July 1948, Australian Delegation at ECOSOC to DEA, 4 August 1948', NAA: A1838, 856/20 Part 3.

42 Buckley et al., Doc Evatt, 278.

43 These differences were not helped by suspicions about Soviet sympathisers within the Australian government. See, Frank Cain, 'Venona in Australia and its Long-Term Ramifications', Journal of Contemporary History 35, no. 2 (2000): 231-48.

44 Wayne Reynolds, Australia's Bid for the Atomic Bomb (Melbourne: Melbourne University Press, 2000), 74-91; Peter Morton, Fire Across the Desert: Woomera and the Anglo-Australian Joint Project 1946-1980 (Canberra: AGPS, 1989), 52-7, 63-9, 103-33. 
developing this machinery with a major defence review. The review, which considered national defence needs in the event of a global war, promoted the regionalisation of Commonwealth defence as the basis of a world system for security. As Defence Minister John Dedman explained:

This means that each member of the Empire has a primary responsibility in regard to its own problem in its particular region, which requires working out, not only with the other members of the Empire concerned, but also with other nations with territorial and strategic interests in that area. If you piece these regional arrangements together you achieve a major contribution to an overall plan, whether on a British Commonwealth or a world basis. ${ }^{45}$

Within this system, Australia would be 'the main support area' for South-East Asia and the South Pacific and would, 'from time to time', act 'on behalf of the rest of the Commonwealth' in matters relating to the region. ${ }^{46}$

In 1947, Australia had been hopeful about securing a CommonwealthUS defence arrangement. By 1948, with the Reverse Course in Japan and America's refusal to make specific defence commitments, Australia was less optimistic and shifted its focus to a Commonwealth solution for Asia-Pacific security. In October, Evatt attended the 1948 Prime Ministers' Conference. Among his primary aims was determining the 'essential measures required ... to allow Commonwealth countries to integrate successfully in the event of war'. This included high-level strategic planning, equipment standardisation and determining areas of strategic responsibility. ${ }^{47}$ The British delegation tabled a memorandum that reaffirmed its commitment to the regionalisation of defence and the development of a machinery 'to prepare common strategic objectives and organise plans'. ${ }^{48}$ Having read this memorandum, the Australian

45 CPD: Representatives, 4 June 1947, No. 23, 3336.

46 'Doc. 163, Council of Defence Meeting, 12 March 1947', in W.J. Hudson and Wendy Way (eds), Documents on Australian Foreign Policy 1937-49. Volume 12: Australia and the Postwar World 1947 (Canberra: AGPS, 1995) [hereinafter DAFP, vol. 12]. See also, 'Doc. 160, "Appreciation of Certain Aspects of the Strategical Position of Australia", Joint Intelligence Committee Appreciation, 27 March 1947', in Hudson and Way, DAFP, vol. 12.

47 'Boase (Evatt's defence advisor during the 1948 Prime Ministers' Conference) to Shedden (Secretary Department of Defence), 27 September 1948', NAA: A816, 14/301/351.

48 “'Commonwealth Defence Co-operation", Memorandum by British COS, Prime Ministers' Conference, 23 September 1948', in Department of Defence: Correspondence files, multiple number series [Classified 301] [Main correspondence files series of the agency], 1928-62, NAA: A816, $14 / 301 / 351$. 
delegation proposed joint planning on a regional basis-a proposal that was "given the "green light" by the British. ${ }^{49}$ It was on the basis of this joint planning that the Australian, New Zealand and Malayan (ANZAM) defence area was established.

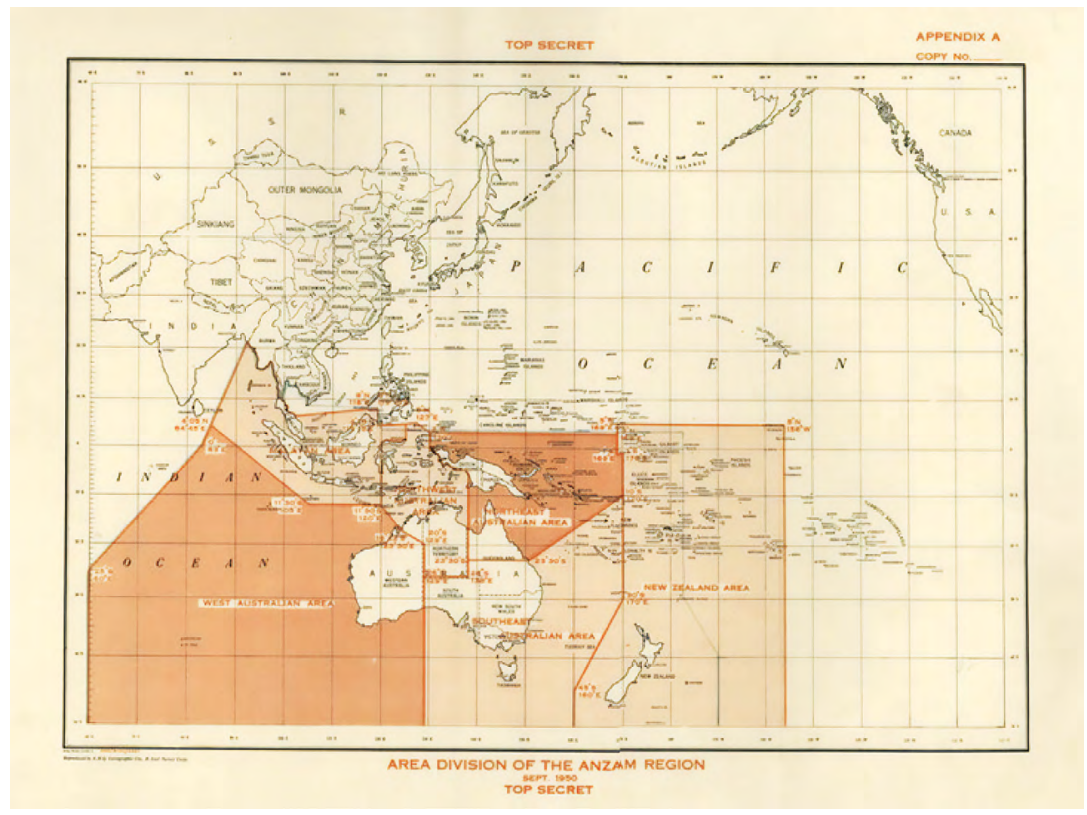

\section{Figure 6.1 ANZAM defence area}

Source: Courtesy of National Archives of Australia, NAA: A5954, 1419/13.

Established over a series of joint planning discussions in late 1948 and 1949, ANZAM was both an area of strategic responsibility and the machinery for Australian, British and New Zealand strategic planning. ANZAM provided the basis for defence responsibilities in peacetime and the command structure in the event of war. Effective consultation was achieved through the appointment of British and New Zealand liaison officers, stationed in Australia. Within the ANZAM area, Australia assumed overall responsibility for the lines of sea communication and home defence, New Zealand assumed responsibility for its home defence and Britain for the defence of Malaya and other possessions in the area. Regular consultation aimed to provide for relatively cohesive planning

49 'Boase to Shedden, 18 October 1948', NAA: A816, 14/301/351. 
for 'co-ordination with overall planning in the Anzam Area'. ${ }^{50}$ Spanning from the Indian Ocean across to the Cook Islands in the South Pacific Ocean and up from New Zealand to Malaya, the ANZAM area effectively codified Australia's strategic zone of responsibility as demarcated in the 1944 ANZAC Agreement.

\section{Responding to regional nationalism}

America's declining interest in Australia's immediate region and the Reverse Course in the management of occupied Japan coincided with an upsurge of Asian nationalism, making regional engagement a more complicated and urgent task. Asian nationalism rendered trusteeship and the gradual move towards self-determination-the preferred method for trustee nations and the basis of Australia's plan for engaging with the islands to its north-effectively redundant. Australia's response was to reinforce its commitment to developing its diplomatic capabilities, principally in the role of a good neighbour and partner in realising the aspirations of its regional community.

Where the US and Britain tended to see the hand of the Soviet Union and ideological expansionism in the Asian nationalist movement, the Chifley government was broadly supportive and sought to accommodate the changing regional landscape within its foreign policy. This was particularly true of John Burton, Evatt's private secretary (1941-47) and DEA secretary (1947-50), who saw in the Asian nationalist movement legitimate aspirations worthy of support. ${ }^{51}$ Australia's position on Asian nationalism has produced scholarly assessments pointing to a profound shift in Anglo-Australian relations. Christopher Waters, for instance, argues that Australia was 'bitterly to disappoint' the British government in its resistance to the narrative of a Soviet-inspired movement. ${ }^{52}$ More critically, in supporting Indonesian independence and standing against

50 Hiroyuki Umetsu, 'The Origins of the British Commonwealth Strategic Reserve: The UK Proposal to Revitalise ANZAM and the Increased Australian Defence Commitment to Malaya', Australian Journal of Politics and History 50, no. 4 (2004): 509-25, at pp. 510-11; "Procedure for Future Planning in Relation to British Commonwealth Defence in ANZAM Area”, Defence Committee Report, revised copy following Joint Planning discussions, 26 August 1949', NAA: A5954, 1626/4.

51 Adam Hughes Henry, 'John Burton: Forgotten Mandarin?', in The Seven Dwarfs and the Age of the Mandarins: Australian Government Administration in the Post-War Reconstruction Era, ed. Samuel Furphy (Canberra: ANU Press, 2015), 221; Henry, The Gatekeepers of Australian Foreign Policy, 2-3.

52 Waters, The Empire Fractures, 168-9, 171-4. 
the Netherlands at the UN—a move the British had cautioned againstAustralia effectively undermined the legitimacy of Britain's own claims in South-East Asia and the South Pacific. ${ }^{53}$ The Chifley and Clement Attlee governments certainly differed in their assessments of the USSR. When it came to Asian nationalism, Australia's response sought to deliver a regional system that reinforced the Commonwealth's influence.

Australia's response to Asian nationalism attempted to encourage stability and reform its regional identity. Supporting the economic aspirations of the nationalists was central to this task. In early 1947, the Australian economist and public servant H.C. Coombs wrote to the prime minister offering his personal suggestions on how best to respond to Asian nationalism. He believed it 'unwise' to allow political differences to lead Australia to 'oppose in any way the achievement of the legitimate economic aspirations of these peoples'. Coombs concluded that the Australian government 'should make a conscious attempt to identify herself with these developments'. ${ }^{54}$ Coombs was by no means the first to note the relationship between economic development, diplomacy and regional stability. However, his position as director-general of the Department of Post-War Reconstruction and closeness to Chifley, as both an advisor and a friend, placed him among the most influential public servants in postwar Australia. It is significant, then, that these comments have been overlooked elsewhere.

While the Chifley government has been accused of betraying the Commonwealth in its response to Asian nationalism, there is much to suggest the government conceived of the changing political forces in South-East Asia and the Pacific as an opportunity to redefine and extend Commonwealth influence in the region. In a statement to the House of Representatives in June 1947, Evatt argued that Britain and the Pacific dominions had a responsibility to the region, calling on them to play their 'due part ... in helping the peoples of these areas achieve their legitimate nationalist aspirations'. He made a clear link between these so-called regional responsibilities and safeguarding Commonwealth interests.

53 For discussion of Australia's role in Indonesian independence, see Peter Denis, 'Australia and Indonesia: The Early Years', in Australia and the End of Empires: The Impact of Decolonisation on Australia's Near North, 1945-65, ed. David Lowe (Geelong, Vic.: Deakin University Press, 1996), 43-52; George, Australia and the Indonesian Revolution.

54 'Coombs to Chifley, 11 February 1947', in Department of External Affairs: Correspondence files, multiple number series with year prefix [Main correspondence files series of the agency], 1933-71, NAA: A1068, ER47/70/7. 
He encouraged Britain, Australia and New Zealand to cooperate in developing regional awareness, believing the two Pacific dominions were geographically positioned to provide 'special area knowledge' that could inform 'what is best likely to preserve British Commonwealth interests in this part of the world'.55

India was among the most important tests of Australia's support for Asian nationalism. While the Chifley government welcomed India's independence in 1947, it was vocal about its desire to see the nation remain a member of the Commonwealth. Evatt underscored the freedom and security Australia enjoyed as a dominion in a statement to the House of Representatives:

The Australian Government, as a member of the British Commonwealth of Nations, enjoying a status of complete freedom and autonomy in both domestic and foreign policies, has looked forward to the achievement by India of a similar status and a similar freedom. The people of India should be fully aware of this free and autonomous position of Australia and other members of the British group of nations. On this view India could pursue all its national aspirations while still maintaining the link by which all members of the British Commonwealth are bound together. ${ }^{56}$

Australia ultimately supported Indian membership as a republic, owing no allegiance to the Crown but still committed to the Commonwealth and the British world system.

The Chifley government's enthusiasm for India's continuing Commonwealth membership rested on delivering strategic capabilities. Not only was India an important member of the Sterling Area and central to British commercial power; it was also defensively significant. As Commonwealth defence planning moved towards regionalisation, the Australian government identified an opportunity to draw India into a defence arrangement. India would act as 'a main support area', defending sea lines of communication adjacent to ANZAM and taking on greater responsibility in Middle Eastern defence. ${ }^{57}$ Although the Chifley government did not successfully secure a defence arrangement with India,

\footnotetext{
55 CPD: Representatives, 5 June 1947, No. 23, 367-8.

56 CPD: Representatives, 26 February 1947, No. 9, 164-5.

57 Frank Bongiorno, 'British to the Bootstraps? H.V. Evatt, J.B. Chifley and Australian Policy on Indian Membership of the Commonwealth, 1947-49', Historical Studies 36, no. 125 (2005): 18-39; Reynolds, 'Imperial Defence After 1945', 124-6; Buckley et al., Doc Evatt, 296.
} 
it continued to promote closer relations with this important neighbour. Australia consistently aligned itself with India on matters of regional importance at various meetings of Commonwealth ministers and at the 1947 and 1949 New Delhi conferences. ${ }^{58}$

By mid-1948, the Asian nationalist movement was gaining momentum: there was agitation in Malaya, India had gained independence from Britain and Burma and Ceylon (Sri Lanka) followed in 1948. The DEA acted on the ideas presented by Coombs, Evatt and others, appointing a goodwill mission to South-East and East Asia. The genesis of the mission was a tour of the region carried out by the British Council—a British government-funded body designed to promote greater international knowledge of British culture. Following this tour, Britain requested the Australian government contribute to a cultural diplomacy program that would 'ensure the spread of British ideas and influence ... and prevent other foreign influences from supplanting British influence there. ${ }^{59}$ Macmahon Ball was appointed leader of the mission. As a prominent public intellectual, a close observer of Asian politics and an experienced diplomat, he was well suited to the task. ${ }^{60}$ Australia committed to providing scholarships and relief aid; these plans were later broadened to include the provision of supplies under UN rehabilitation and development schemes. ${ }^{61}$ The mission was also investigatory in nature, providing an opportunity to make contact with local officials and nationalist leaders to better understand the region and determine future development needs.

Macmahon Ball presented his report on the mission to the federal government in July 1948. Above all else, he recommended Australia invest in the economic aspirations of Asia, including the continued provision of scholarships and relief aid. Macmahon Ball was particularly focused on education:

58 David Fettling, An Australian Response to Asian Decolonisation: Jawaharlal Nehru, John Burton and the New Delhi Conference on Non-Western Nations', Australian Historical Studies 45, no. 2 (2014): 202-19; Julie Suares, 'Engaging with Asia: The Chifley Government and the New Delhi Conferences of 1947 and 1949', Australian Journal of Politics and History 57, no. 4 (2011): 495-510.

59 'Doc. 155, Cabinet Submission by Chifley and Pollard (Minister for Post-War Reconstruction), 12 January 1948', in Pamela Andre (ed.), Documents on Australian Foreign Policy 1937-49. Volume 14: The Commonwealth, Asia and the Pacific, 1948-49 (Canberra: AGPS, 1998) [hereinafter DAFP, vol. 14].

60 Cotton, The Australian School of International Relations, 181, 187-8.

61 'Doc. 156, Press Statement by DEA, 16 May 1948', in Andre, DAFP, vol. 14. 
Technical and intellectual aid is singularly important in these countries since so many of the new governments are controlled by students. These are young men with enough intelligence to understand what they lack in training and experience. To win the friendship and goodwill of the students and technicians is to win the goodwill of people with great political influence. ${ }^{62}$

The key implication here was that Australia could demonstrate a shift from colonial overseer to a partner in regional affairs, signifying a commitment to engaging in the welfare of the peoples of South-East and East Asia.

Macmahon Ball's suggestions seemingly persuaded the DEA and, in September 1948, an appreciation of the recent developments in the region was carried out. The key theme emerging from this was that the Australian government 'should, by all possible means, encourage countries in the area to look to Australia as an impartial and sympathetic collaborator in their desire to develop stable governments and economic strength'. Existing scholarship programs were expanded and technical and administrative advice provided to local manufacturers and governments. ${ }^{63}$ As we will see, there is a clear link between economic and technical assistance as a means of garnering political influence and the future Colombo Plan. ${ }^{64}$

Key Australian policymakers conceived of the Asian nationalist movement as an opportunity. They hoped to gain greater regional awareness and revitalise the Commonwealth presence in the area. More critically, they could piece together a strategic and diplomatic network in the region, countering America's disinterest in South-East Asia and the South Pacific and its ominous plans for Japan. ${ }^{65}$

Alongside diplomatic and strategic capabilities, Australia was seeking to develop its economic capabilities as part of a cohesive regional system. To fully appreciate the link between trade, diplomacy and security and the Chifley government's thinking on regional engagement, we must consider

62 'Report on a Mission to East Asia, 27 May - 6 July 1948, 27 July 1948', NAA: A6779, 17.

63 '"Survey of Political Events and Trends in South East Asia”, 6 October 1948', NAA: A1068, DL47/5/6.

64 A number of scholars have noted this link, including: Christopher Waters, 'The Macmahon Ball Mission to East Asia 1948', Australian Journal of Politics and History 40, no. 3 (1994): 351-63, at pp. 351-2, 354; Daniel Oakman, Facing Asia: A History of the Colombo Plan (Canberra: Pandanus Books, 2004), 16-18.

65 'Cabinet Agendum Number 11, 2 July 1946, NAA: A6779, Volume 28', cited in Buckley et al., Doc Evatt, 295-6. 
the international order-in particular, the global economic situation, the United States' Cold War plans and the impact this had on British world power.

\section{The international economic situation}

While the world had largely accepted US plans for multilateralism, there were conflicting views and major stumbling blocks on the path to achieving a global multilateral trading system. The greatest of these obstacles was the dollar gap and sterling convertibility crisis.

Before the war, Britain had generally been able to maintain its dollar deficit through surplus sales to other sterling countries. The war upended this balance as Britain's import needs from the US far outstripped its exports. ${ }^{66}$ In July 1946, the Anglo-American loan was signed, granting US $\$ 3.75$ billion to Britain to cover its dollar purchases. However, the US, which believed the removal of protectionist trade practices was the only way to achieve a multilateral world trade system, included the stipulation that the sterling must become convertible to dollars in July 1947. ${ }^{67}$ Within the Sterling Area, Britain effectively acted as the banker, granting permission for members to convert their sterling reserves into dollars to purchase US goods. This system allowed Britain to artificially control the value of the sterling and ration US exports to the Sterling Area. By enforcing convertibility, the US would reduce the effectiveness of Sterling Area discrimination. ${ }^{68}$

When sterling became convertible on 15 July 1947, Britain's trading partners quickly sought to convert their sterling into dollars, for revenue and capital transactions alike. This forced Britain to draw on its dollar loan at a rate that would exhaust reserves by the end of the year. An emergency Cabinet meeting was called in mid-August and sterling convertibility was suspended indefinitely. Contrary to US hopes, Britain recommitted itself to the Sterling Area. Dollar pooling arrangements were reintroduced and Britain agreed to sell dollars for sterling to Sterling Area members that

66 Scott Newton, 'Britain, the Sterling Area and European Integration, 1945-50', in Money, Finance and Empire, 1790-1960, eds A.N. Porter and R.F. Holland (London: Frank Cass, 1985), 163-5.

67 Francine McKenzie, Redefining the Bonds of Commonwealth, 138-55.

68 Scott Newton, 'The Sterling Crisis of 1947 and the British Response to the Marshall Plan', Economic History Review 37, no. 3 (1984): 391-408, at pp. 392-3. 
needed to balance deficits if those members drastically limited their dollar spending. The Sterling Area was reinstated as an insular and discriminatory system of trade and finance. ${ }^{69}$

Although Australia agreed to limit its dollar purchases - the rationing of foodstuffs and fuel saw imports from the US fall from 19.10 per cent to 10.03 per cent of total imports between 1946-47 and 1948-49-it adopted these measures with some reservations. ${ }^{70}$ The war had driven home to Australia the dangers of dependency on foreign markets for defence goods, and the postwar reconstruction program was a longterm solution for greater industrial capacity. ${ }^{71}$ To achieve industrial self-sufficiency, Australia needed new import and export markets. Even before the conversion crisis, there were those in Australian political circles mindful of the risk of economic dependency on Britain. In February 1947, Coombs, for example, warned Chifley against overdependence on the Sterling Area. He believed Britain faced a 'desperate economic situation'. The nation's purchasing power was depleted, economic growth was stagnant and it was already clear it was beyond its capacity to absorb the volume of Australian produce needed to avoid a deficit. Australia should continue to support the Sterling Area, Coombs argued, benefiting from preferential treatment while planning 'consciously to reduce our dependence on the United Kingdom market'. With British purchases making up 29 per cent of all Australian exports and more than 35 per cent of imports, this would have to be a gradual process. With this in mind, Coombs encouraged Chifley to explore trade opportunities with the newly independent Asian nations-namely, India, with hopes to build on existing goodwill between the two nations. ${ }^{72}$

By July 1947, Coombs was considering more hasty steps towards greater economic self-sufficiency. In his private notes, he anticipated a recession by the close of the year as well as Britain's retreat to the economies of Western Europe. Coombs believed Australia's policy must be 'to cushion the effects'

69 Lee, 'Protecting the Sterling Area', 183; Newton, 'The Sterling Crisis of 1947 and the British Response to the Marshall Plan', 394-401; 'Statement by Chifley in the House of Representatives, 4 December 1947', in John G. Crawford (ed.), Australian Trade Policy 1942-66: A Documentary History (Canberra: Australian National University Press, 1968), 105-9.

70 Official Year Book of the Commonwealth of Australia, No. 38 (Canberra: Commonwealth Government Printer, 1951), 483-5.

71 Tim Rooth, 'Imperial Self-Insufficiency Rediscovered: Britain and Australia, 1945-51', Australian Economic History Review 39, no. 1 (1999): 29-51, at pp. 29-32.

72 Official Year Book of the Commonwealth of Australia, No. 38 (1951), 483; 'Coombs to Chifley, 11 February 1947’, NAA: A1068, ER47/70/7. Figures are for the financial year 1946-47. 
of these developments - in other words, reducing dependency on Britain and the US. The principal cushion Coombs proposed was a long-term plan to develop a larger proportion of Australian trade with South-East Asian and Pacific countries. This included promoting Australian trade via increased trade representatives and providing technical education and finance. In theory, this assistance in the economic development of South-East Asian and Pacific nations would be remunerated in purchases from Australia. ${ }^{73}$

There is no evidence that Coombs shared these views with his colleagues, however, his suggestions mirrored the DEA's strategic interests in regional affairs and development initiatives such as the SPC. His ideas were also mirrored in the emerging Commonwealth policy that attempted to solve the dollar gap and safeguard the future of Commonwealth commercial interests in South-East Asia. To understand how this Commonwealth policy developed, we must look to Cold War tensions and the United States' economic attempts to secure Europe.

Following the 1947 sterling conversion crisis, the US feared economic crisis in Western Europe would create instability and opportunities for Soviet domination. The US government believed Europe's dire economic situation was the result of a 'failure ... to produce', forcing these countries to buy from the US without any hope of selling enough in return. ${ }^{74}$ The solution was, as Secretary of State George C. Marshall argued, to rehabilitate the European economic structure, allowing it to produce exports for the dollar market that would, in time, establish an equilibrium. Marshall's assessment was the origin of the European Recovery Program (ERP, or Marshall Plan), which aimed to stimulate production by way of dollar aid, thereby creating the conditions for an integrated Europe that was part of a global multilateral economy in which the dollar ruled. ${ }^{75}$

Facing a desperate economic situation, the British government welcomed dollar aid, although not without some reservations. Britain pinned its hopes of rebuilding global power on the Sterling Area and the restoration

73 'Rough Notes on Personal Letter, authored by Coombs, 3 July 1947', NAA: A1068, ER47/70/7.

74 'Doc. 164, Memorandum of Conversation, meeting of Clayton (Under Secretary of State) and British Cabinet Members, 25 June 1947', in Ralph E. Goodwin, Marvin W. Kranz, David H. Stauffer, Howard M. Smyth, O.N. Sappington, Fredrick Aandahl, Rogers P. Churchill and William Slany (eds), Foreign Relations of the United States, 1947, The British Commonwealth; Europe, Volume III (Washington, DC: US Government Printing Office, 1972) [hereinafter FRUS 1947].

75 Schaller, The American Occupation of Japan, 87, 96-7; 'Doc. 140, Press Release Issued by the Department of State, 4 June 1947, Remarks by Marshall', in Goodwin et al., FRUS 1947. 
of its colonial empire in the Asia-Pacific. Britain's trading relationships were based on imperial links and the ability to offset dollar deficits through the dollar-earning capacity of the Sterling Area countries, many of which were British territories or former territories in South-East Asia. Britain provided sterling and soft currency credit to these nations, which exported raw materials and consumer goods to the US. The dollars earnt in these sales were used to repay the British, and then deposited in the dollar pool. If the underdeveloped Sterling Area countries did not develop concurrently with Europe, there was the risk of a rapid drain on the dollar pool, eventually leading to the sterling becoming unviable. ${ }^{76}$ The ERP conceived of the dollar problem as a European problem and accordingly sought to solve it through a regional approach. Britain, along with much of the Commonwealth, not only believed the dollar problem was an international one in which global economic rehabilitation and US commitments to full employment and greater purchases would be more effective, but also did not wish to become fully integrated into a European economy. Despite Britain's insistence that the dollar problem was a global one, no dollar aid was granted to the Sterling Area for it fit within neither the United States' Cold War strategic outlook nor its vision for multilateralism, centred as it was on dismantling discriminatory trade practices. ${ }^{77}$

\section{South-East Asia, the solution to the dollar problem?}

The problems apparent in the ERP were first discussed in depth by Australian and British officials when Chifley took part in economic discussions with British Cabinet ministers in July 1948 and Evatt attended the 1948 Commonwealth Prime Ministers' Conference. In the months preceding the conference, some in the Australian Treasury Department had raised concerns that the Marshall Plan would lead Britain to become increasingly reliant on Europe for both exports and imports. This would further limit Australia’s export capabilities, leaving postwar reconstruction

76 Newton, 'The Sterling Crisis of 1947 and the British Response to the Marshall Plan', 391, 394-6; Newton, 'Britain, the Sterling Area and European Integration', 163, 167-9.

77 Tim Rooth, 'Economic Tensions and Conflict in the Commonwealth, 1945-1951', Twentieth Century British History 13, no. 2 (2002): 121-43, at pp. 133, 135-6; Newton, 'The Sterling Crisis of 1947 and the British Response to the Marshall Plan', 395-7; 'Doc. 164, Memorandum of Conversation, 25 June 1947', in Goodwin et al., FRUS 1947. 
projects unfunded and contributing to rising unemployment. ${ }^{78}$ The task for Chifley and Evatt while in London was to find a way to balance the need for dollar imports with the need to conserve dollar spending. ${ }^{79}$

In a meeting with Stafford Cripps, the British Chancellor of the Exchequer, Chifley was informed that, to maintain the sterling reserves at a 'safe level' of $£ 500$ million, Britain would continue to conserve dollar spending, with plans to reduce imports by a further 10 per cent in the coming year. ${ }^{80}$ Cripps stressed that 'everything that Australia can do to reduce her dollar deficit will ease the cut in dollar imports which the UK must make'.$^{81}$ The expectation was clear: as a dominion and member of the Sterling Area, Australia should act to preserve Britain's dollar position, likely at the expense of domestic conditions.

Despite the grim economic outlook, a hopeful long-term solution was presented. The solution was predicated on the stimulation of economic growth in the non-dollar area to create a multilateral system that did not rely on the dollar. To achieve this, Britain and Australia would collaborate in developing the industries of non-dollar countries, prioritising commodities with dollar earning and saving capabilities. ${ }^{82}$ This line of thinking formed the basis of the British government's economic forecast. The long-term economic program aimed to create a multilateral Sterling Area, stabilise sterling reserves and reduce Britain's per annum dollar deficit from $£ 300$ million in 1948 to $£ 100$ million by 1952 . It was hoped these measures would protect the Sterling Area from any economic shock experienced when the ERP ended. ${ }^{83}$

78 'Doc. 6, Nimmo (ABS Officer) to Treasury, 1 March 1948' and 'Doc. 7, Beasley (Australian High Commissioner in London) to Chifley, 27 March 1948', both in Andre, DAFP, vol. 14; 'Questions Relating to the work of the Australian Mission, 5 July 1948', in Department of the Treasury: Correspondence files, multiple number series with year prefix [Main correspondence files series of the agency], 1901-78, NAA: A571, 1948/1840.

79 'Doc. 21, Nimmo to Department of Treasury, 28 June 1948', in Andre, DAFP, vol. 14; “"London Discussions”, 2 July 1947’, NAA: A571, 1948/1840.

80 'Notes on discussion with Cripps, 8 July 1948', NAA: A571, 1948/1840.

81 'Notes on meeting of Chifley, Australian officers and Cripps, 8 July 1948', NAA: A571, $1948 / 1840$.

82 'Notes on meeting of Chifley, Australian officers and Cripps, 8 July 1948' and '“Long Term Policy”, Attached note for Chifley, 8 July 1948', both in NAA: A571, 1948/1840; 'Doc. 22, Notes by Coombs, Notes on Prime Minister's visit to London as reported by Wheeler, 28 July 1948', in Andre, $D A F P$, vol. 14 .

83 'Doc. 22, Notes on Prime Minister's visit to London, 28 July 1948' and 'Doc. 28, Notes by Coombs on First Discussion of Long-Term Program, 22 September 1948', both in Andre, DAFP, vol. 14; 'Minutes Second Meeting of Prime Ministers, 11 October 1948', NAA: A5954, 1790/1. 
When setting out the long-term economic program, Cripps had noted opportunities to develop dollar earning and saving capabilities in SouthEast Asia. ${ }^{84}$ This region not only was home to many of the Sterling Area members, whose exports were mostly the raw materials needed to service industrial output, but also was the main area of British interests caught up in the throes of the nationalist movement. The political and economic significance of South-East Asia was underscored during the Prime Ministers' Conference. The Secretary of State for Foreign Affairs reaffirmed Britain's commitment to the Asia-Pacific and the Middle East - an area he described as the 'middle planet'. ${ }^{85}$ Bevin saw a critical role for Britain and the Commonwealth, arguing that, if this area was carefully organised, it could become

an equilibrium between the United States on the one hand and Russia on the other. The great Powers represented rival ideologies ... Between them was the United Kingdom, with her ties to the Commonwealth and with Europe. Here was an opportunity ... to prevent the middle of the world from becoming embroiled in a conflict and to exert their [British Commonwealth] influence in preserving world peace. ${ }^{86}$

In this undertaking, Bevin encouraged interested Commonwealth members to establish a means of regular consultation 'with the object of helping to put the political and economic life of countries in SouthEast Asia on a firm footing. ${ }^{87}$ While Bevin was particularly concerned that the area would be drawn into the Soviet sphere-a consideration not yet dominating Australian policymaking-his emphasis on economic development as a means of garnering Commonwealth influence nevertheless resonated with earlier assessments made by Australian policymakers.

Evatt immediately seized on the link between Bevin's foreign policy appraisal and recent thinking on the dollar problem. He thanked Bevin for the attention given to 'the development of backward areas', describing

84 'Meeting of Chifley, Australian officers and Cripps, 8 July 1948' and “'Long Term Policy", 8 July 1948', both in NAA: A571, 1948/1840.

85 Geographical definitions remained relatively fluid during the 1940s, and it should be noted that Bevin actually referenced the Near and Middle East, which would suggest western Asia. However, he proceeded to discuss developments in both western Asia and South-East Asia.

86 'Minutes Third Meeting of Prime Ministers, 12 October 1948', NAA: A5954, 1790/1.

87 ibid. 
it as going 'hand in hand' with the long-term economic program. ${ }^{88}$ Evatt focused on the dollar problem and its implications on engagement with South-East Asian and South Pacific nations. While he supported the longterm economic program, he did have reservations about the uncertainty of plans to develop non-dollar industries for dollar earnings and savings. He called for a concrete framework for promoting growth in non-dollar countries, including the provision of capital equipment, which 'would facilitate industrial development' and, in turn, 'increase the domestic standard of living ... [and] purchasing power to the advantage of Australia and other countries'. These suggestions received support from the other Commonwealth prime ministers-particularly India's Prime Minister Pandit Jawaharlal Nehru—but did not result in any coherent policy. ${ }^{89}$

Nevertheless, both the long-term economic program and discussions at the Prime Ministers' Conference are significant. They indicate the genesis of a Commonwealth response to the dollar problem-one centred on preserving British commercial power and the Sterling Area trade relationship in the face of challenges presented by the US-led economic order. Given the Chifley government's appreciation of the value of economic development for promoting regional stability and developing future markets, Australia's support for Commonwealth regional economic engagement as a solution to the dollar problem can be seen as intertwined with plans to develop the nation's strategic and diplomatic capabilities.

The dollar problem continued to intensify when the US experienced a sharp downturn in private sector investment and domestic consumption, sending the nation into a year-long recession from November 1948. The US restricted its already small non-dollar imports, while the Sterling Area continued to make dollar purchases. This situation led to a large drop in the Sterling Area's reserves — of some $\$ 300$ million in the first quarter of $1949 .{ }^{90}$ Unless the dollar gap was quickly corrected, the Sterling Area would face a recession, necessitating further protectionist measures and quashing all hopes for a multilateral world trading system. ${ }^{91}$

88 ibid.

89 'Minutes Fifth Meeting of Prime Ministers, 13 October 1948', NAA: A5954, 1790/1.

90 'Attachment, "Notes on the Dollar Problem", Coombs to Dedman, 7 July 1949', Papers of

J.J. Dedman, NLA: MS 987/14/23-30.

91 Lee, 'Protecting the Sterling Area', 188-9. 
In early July 1949, US-British treasury discussions were held, and the following week an emergency meeting of the Commonwealth finance ministers was convened in London to discuss the available options. The British government hoped to secure a long-term compromise with the US-one that acknowledged the importance of an equilibrium between the dollar and the Sterling Area in achieving a multilateral trading system. In the discussions with the US, the British tabled such a compromise, indicating it would improve expenditure and increase export sales in exchange for lower tariffs, continued recovery aid and increased purchases from the Sterling Area. ${ }^{92}$ In the coming months, the US government realised the dollar problem was increasingly becoming a Cold War problem and there were no gains to be had in the collapse of the Sterling Area. The US eventually agreed to cooperate in the proposed compromise. ${ }^{93}$

Although the British government had emphasised the importance of establishing multilateralism in its negotiations with the US, the Sterling Area remained the priority. According to a report produced following the emergency meeting of the Commonwealth finance ministers, all ministers present agreed that 'rebuilding the sterling reserves as quickly as possible was of paramount importance' and they would make 'practicable contribution[s] to this end'. This involved making their economies as attractive as possible to dollar countries through the introduction of currency devaluation and tax incentives. As had been discussed in the long-term economic program and at the 1948 Prime Ministers' Conference, the underdeveloped Sterling Area countries had a key role to play. There were plans to invest in these countries so they could become competitive producers of 'those commodities which can earn dollars or which the sterling area would otherwise have to purchase for dollars' ${ }^{94}$ As the Cold War intensified during the closing months of 1949 and into 1950 , the Commonwealth was finally offered an opportunity to integrate these tentative proposals into the United States' international outlook.

92 'Meeting of Commonwealth Finance Ministers, Recommendations to Governments, [n.d. (July 1949)]', NLA: MS 987/14/147-53; 'Doc. 440, Snyder (Secretary of the Treasury) to Acheson (Secretary of State), 9 July 1949' and 'Doc. 441, Snyder to Acheson, 10 July 1949', both in David H. Stauffer, Frederick Aandahl, Charles S. Sampson, Howard McGaw Smyth and Joan Ellen Corbett (eds), Foreign Relations of the United States, 1949, Western Europe, Volume IV (Washington, DC: US Government Printing Office, 1974) [hereinafter FRUS 1949].

93 Lee, 'Protecting the Sterling Area', 190-1; 'Doc. 449, Position Paper for the Discussions with the British and Canadians on Pound-Dollar Problems, Prepared by the Policy Planning Staff, 3 September 1949', in Stauffer et al., FRUS 1949.

94 'Meeting of Commonwealth Finance Ministers, Recommendations to Governments, [n.d. (July 1949)]', NLA: MS 987/14/147-53. 


\section{Opportunities for Australian-US cooperation as the Cold War enters Asia}

On 1 October 1949, the Cold War swept dramatically into Asia when the Chinese Communist Party proclaimed the People's Republic of China. This development contributed to an increasing consensus between the Department of Defence and the DEA, the two departments having previously clashed over the strategic prioritisation of South-East Asia and the threat posed by communism. ${ }^{95}$ On the basis of the changed strategic outlook, Burton organised a series of interdepartmental discussions to work towards consistency across departments when it came to regional policy. In addition to the ministers and senior officials from the departments of Trade and Customs, Commerce and Agriculture, Defence, and External Affairs, the Chifley government called home its diplomatic representatives from China, Indonesia, Japan, Malaya, the Philippines and Thailand. Officials from Britain and New Zealand were also invited to attend the plenary sessions as observers. ${ }^{96}$

Burton's working paper and final summary of the discussions clearly set out the framework for Australia's future policy approach in its region. These two documents detailed fears that communist forces would use the arc of islands to Australia's north as 'stepping stones' to the continent. Political and economic stability were central to the protection of this area, avoiding the development of an environment that would allow communism to take hold. It was agreed that Australia should implement positive measures in the region to aid the development of stable and moderate states that would act as a 'buffer region between us and the Asian mainland'. Proposed measures included expanding bilateral trade, new diplomatic appointments-contacts who would not only extend

95 'Joint Intelligence Committee Report 72/1949, 8 February 1949' and 'Moodie (Officer in Administrative and General Division, DEA) to Joint Intelligence Committee, 24 May 1949', both in NAA: A1068, DL 47/5/6. For a full account of DEA-Defence tensions, see Christopher Waters, 'The Great Debates: H.V. Evatt and the Department of External Affairs, 1941-49', in Ministers, Mandarins and Diplomats: Australian Foreign Policy Making, 1941-1969, eds Joan Beaumont, Christopher Waters, David Lowe and Gary Woodard (Melbourne: Melbourne University Press, 2003), 45-61.

96 '“Australian Policy in South East Asia”, report prepared for Burton, 12 December 1949', NAA: A1068, DL 47/5/6. 
goodwill, but also serve as a channel for intelligence 'gathered on the spot with an eye to specific Australian requirements'-and the provision of technical and financial assistance in the region. ${ }^{97}$

Considering the centrality of economic development to the Chifley government's previous responses to Asian nationalism and the dollar problem, Burton's emphasis on investing in regional economic development to combat communism was not particularly novel. What was new, however, was that Australia's plans for regional engagement were beginning to accommodate the US and its Cold War outlook. Not only was there an expressed willingness to cooperate with the US in providing assistance in South-East Asia, but also there was a changing assessment of Japan. The department heads agreed it was in Australia's strategic interest that the rehabilitation of the Japanese economy continue, at least in so far as the communist victory in China had resulted in the loss of a large market for South-East Asian and Pacific nations and Japan represented an alternative market. ${ }^{98}$ Although Australia still treated Japan with caution, this softening position indicated a renewed willingness to cooperate with US plans. Fortuitously, the Truman administration was also reassessing its policy in the Asia-Pacific region, with outcomes overlapping with many of Australia's own priorities.

The US had developed a policy for Japan as the bulwark against the USSR. Following the communist victory in China, however, the fear was that it had been the neglect of the rest of Asia that had allowed Soviet influence to expand into China. ${ }^{99}$ In November, the State Department presented President Truman with a brief considering how best to remedy this neglect. The communist victory in China was seen as emblematic of the new 'tool of ... Russian imperialism in the Far East', and it was feared that Soviet influence would spread from mainland Asia down through the 'weak and vulnerable' South-East Asian nations. The State Department advised the president to support a program of moral and material aid to strengthen the area against a communist insurgency. Japan's continued economic growth was fundamentally tied to this program. The nation's political and economic progress would demonstrate to others 'the advantages of

97 “'Australia and Southeast Asia”, Burton working paper for Interdepartmental Discussions, 13 November 1949' and “'Australian Policy in South East Asia”, 12 December 1949', both in NAA: A1068, DL47/5/6.

98 “'Australian Policy in South East Asia”, 12 December 1949', NAA: A1068, DL47/5/6.

99 Claire L. Chennault, 'The Chinese Civil War: What We Face in the Far East', Vital Speeches of the Day 15, no. 15 (1949): 468-70. 
close association with the United States'. More critically, as the SouthEast Asian nations developed and their purchasing power increased, Japan would offer an alternative regional market to China and the USSR. ${ }^{100}$

The State Department's November report stressed the urgency of settling the Japanese peace treaty. This advice reinforced earlier reports, including those from the NSC. The US recognised that the peace treaty would give Japan the legitimacy and implied reform necessary for the nation to take its place among the Asia-Pacific community. There was also the opportunity to formalise the use of Japanese territory for US bases in the peace treaty's terms. ${ }^{101}$ The report went on to inform US Cold War policy in Asialargely contained in NSC policy paper 48/2, approved on 30 December 1949. The central tenant of NSC $48 / 2$ was that the US would provide economic, technical and military assistance to friendly Asia-Pacific nations in an attempt to increase the present Western orientation of the area and to assist, within our capabilities, its governments in their efforts to meet the minimum aspirations of their people and to maintain internal security'. Japan was at the top of the list of nations to be supported, with plans to include MFN status in the Pacific peace treaty to ensure Japan was positioned for economic recovery and its eventual development as a regional economic hub. ${ }^{102}$

By late 1949, not only was the US government ready to negotiate Japanese peace, but also it had acknowledged the significance of South-East Asian countries, both in the sustainability of a multilateral trade system and in containing the spread of communism. The US was willing to provide these countries with the economic aid for which the Commonwealth had been calling since the implementation of the ERP. This convergence of Australian and US interests marked a renewed opportunity for regional cooperation. We know that Australia was aware of these opportunities because of reports received from the Australian Embassy in Washingtonwith one such report remarking that US 'foreign policy has turned from

100 'Doc. 386, Memorandum by Jessup (Ambassador at Large) to Acheson, 16 November 1949, Attachment, "Outline of Far Eastern and Asian Policy for Review with the President", 14 November 1949', in John G. Reid and John P. Glennon (eds), Foreign Relations of the United States, 1949, The Far East and Australasia, Volume VII, Part 2 (Washington, DC: US Government Printing Office, 1976) [hereinafter FRUS 1949].

101 'Doc. 70, "Recommendations with Respect to US Policy Toward Japan", Report by the NSC, 6 May 1949' and 'Doc. 386, "Outline of Far Eastern and Asian Policy for Review with the President", 14 November 1949', both in Reid and Glennon, FRUS 1949.

102 'Doc. 387, "The Position of the US with Respect to Asia", Report to the President by the NSC, 30 December 1949', in Reid and Glennon, FRUS 1949. 
Europe to [the] Far East' - and because NSC 48/2 was mentioned either directly or in passing in a number of press releases and newspapers articles collected by the DEA. ${ }^{103}$

The Chifley government was never able to capitalise on these opportunities or transfer to tangible policy the strategies developed during the later half of 1949, being defeated by Robert Menzies' coalition government in the December election. Nevertheless, as David Lowe has noted, the foreign policy thinking of the Chifley government, particularly that which developed in the years 1948 to 1949 , went on to inform the Menzies government's early position towards Australia's regional role and relationships with the Commonwealth and the US. ${ }^{104}$

\section{The Colombo Plan as a constructive approach to the dollar problem}

In January 1950, the Commonwealth Foreign Ministers' Conference was held in the Ceylonese capital of Colombo to discuss the political and economic implications of the communist victory in China. Australia's representative was the new Minister for External Affairs, Percy Spender. Spender, who was ambitious and well versed in the geopolitics of Australia's region, began his 16-month stint as minister with gusto. He hoped to transform tentative aid proposals into a concerted Commonwealth plan. The meeting in Colombo was the ideal platform to achieve this. Spender proposed a cooperative assistance program in South-East Asia that would create a standard of living 'under which the ideological attractions which communism exerts will lose their force'. ${ }^{105}$ Along with a similar proposal from Ceylon's Foreign Minister, Spender's proposal went on to form the Colombo Plan.

103 These press releases and newspaper articles can be found in NAA: A1838, 3103/11/161 Part 4; 'Crisis in Asia: An Examination of US Policy, Remarks by Acheson, 12 January 1950', Department of State Bulletin: Far Eastern Series 32 (1950): 111-18.

104 David Lowe, Menzies and the 'Great World Struggle': Australia's Cold War, 1948-1954 (Sydney: UNSW Press, 1999), 37.

105 'Doc. 16, "Economic Policy in South and South-East Asia", Memorandum by Australian Delegation to the Commonwealth Meeting of Foreign Ministers, 11 January 1950', in David Lowe and Daniel Oakman (eds), Documents on Australian Foreign Policy. Volume 24: Australia and the Colombo Plan, 1949-1957 (Canberra: DFAT, 2004) [hereinafter DAFP, vol. 24]. 
As an anti-communist program, the Colombo Plan tends to be seen through a Cold War lens-designed to capitalise on the symbolic importance of cultural and economic engagement in fighting the Cold War in Asia as well as mirroring Australia's foreign policy with that of the US, like the Point Four Program, with hopes this would lead to a regional defence arrangement. Spender's emphasis on enlisting US support for the Colombo Plan-in particular, his private message to Menzies that this was 'the main tactical objective'-leaves little doubt the Colombo Plan was a strategic solution to Asia's sudden entrance into the Cold War. ${ }^{106}$ A solely strategic assessment of the Colombo Plan, however, overlooks the ideas about diplomatic and economic capacity-building and Commonwealth influence that had evolved during the Chifley years. As the centre of gravity of world affairs began to shift towards South-East Asia, 1950 provided the moment in which this thinking could be shaped into policy and integrated within the United States' international outlook.

The principal evidence that the economic capacity of the Sterling Area played a role in the Colombo Plan can be found in some rather neglected discussions during the 1950 Foreign Ministers' Conference. During the second session of the conference, the dollar problem was described as a Cold War problem. All present agreed that if there was a sudden financial crisis because of the dollar problem, a drop in the standard of living would invariably follow, providing the communists with the political and economic environment in which to flourish. To combat this, production would have to be increased across the non-communist world, promoting a unified and stable trading system. ${ }^{107}$ The link between the dollar problem, Commonwealth economic power and the Colombo Plan was more clearly noted in the eighth session of the conference. According to Spender:

[T] he fuller economic development of South-East Asia would bring great benefits not only to the region itself but also to other parts of the world and, in particular, would contribute to the solution of the monetary problems of the sterling area. The negative policy of reducing dollar imports could not provide a permanent solution. The economic development of South-East Asia would provide a more constructive approach to this problem. ${ }^{108}$

106 'Doc. 17, Spender to Menzies, 11 January 1950', Lowe and Oakman, DAFP, vol. 24.

107 'Minutes Second Meeting of Foreign Ministers, 9 January 1950', NAA: A1838, 532/5/2/1.

108 'Minutes Eighth Meeting of Foreign Ministers, 12 January 1950', NAA: A1838, 532/5/2/1. 
He went on to note promising opportunities for raw materials and food, 'for which there was a ready market in dollar countries'. ${ }^{109}$ Spender echoed tentative Commonwealth plans presented in the long-term economic program, seeking to reorient finance away from Europe and build up the Sterling Area as a market for dollar earnings and savings. These revelatory documents have been overlooked in histories of the Colombo Plan; nor are they included in the DFAT volume on the plan or the single Australianauthored historical monograph dedicated to it. ${ }^{110}$

The Colombo Plan discussions were informed by the desire to invite the US to contribute to a region in which the weight of Commonwealth economic interests was evident. The US accepted in principle the strategic importance of greater dollar and sterling equilibrium and the need to incorporate technical assistance into its South-East Asian policy, but little progress had been made. This sluggishness was due to the State Department's reluctance to initiate the provision of material support to regional associations, lest it be accused of using Asian nationalism to further its strategic ambitions. ${ }^{111}$ While there was an opportunity to attract dollar investment in an area that was so critical to Commonwealth commercial and strategic power, it had to be carried out prudently. In the memorandum outlining the Colombo Plan, Spender noted that SouthEast Asia's new significance in the Cold War 'make[s] timely a high-level approach to the United States Government to represent the views of [the] Commonwealth ... on the political and economic situation and the need for economic support'. ${ }^{112}$ The conference delegates supported Spender's recommendations and plans were made to reconvene in the coming May to discuss the implementation of the Colombo Plan. However, it was cautioned that 'any published version of the recommendations should be carefully worded, so as to avoid any possibility of misunderstanding. ${ }^{113}$ Presumably, this meant placing Cold War imperatives rather than the dollar problem at the forefront of discussion, as well as avoiding a brash request for US financial assistance.

109 ibid.

110 Lowe and Oakman, DAFP, vol. 24; Oakman, Facing Asia.

111 Lowe, 'Percy Spender and the Colombo Plan 1950', 165; 'Spender to DEA, 14 January 1950', Papers of Percy Spender, NLA: MS 4875/1/1.

112 "Economic Policy in South and Southeast Asia", Memorandum by the Australian Delegation to the Meeting of Foreign Ministers, 11 January 1950', in Department of Foreign Affairs and Trade: Unregistered files of the Department of External Affairs, 1920-64, NAA: A9992, 1950/1.

113 'Minutes Eighth Meeting of Foreign Ministers, 12 January 1950', NAA: A1838, 532/5/2/1. 
Of course, the US did not miss the rather thinly veiled ulterior motives of the Colombo Plan. The US Ambassador at Large, Phillip Jessup, noted the problem of sterling balances was 'closely associated' with the Colombo Plan, along with the possibility of being 'presented with a staggering bill' if the US supported the plan. An article in a US newspaper described the upcoming conference in Sydney as

much less a conference to discuss 'Aid to South East Asia' than it is a conference to discuss just how South East Asia can be made to continue its aid to the Commonwealth by supplying goods which the Empire can sell for much needed dollars. ${ }^{114}$

Despite these reservations, the US agreed to join the Colombo Plan in November 1950, officially being admitted in February the following year.

The United States' budding hub-and-spoke alliance system was an important factor contributing to its support for the Colombo Plan. As the Cold War entered Asia, the US was considering formal alliance opportunities in the Asia-Pacific region. In April 1950, the State Department conducted an appraisal of relations with Australia. This document noted that the Menzies government was more sensitive than its predecessor to the threat of communism and willing to cooperate with the US, concluding that this new attitude should not be undervalued nor taken for granted'. This being said, Australiaas continued mistrust of Japan meant it could not necessarily be relied on to support US plans for a lenient peace treaty. The State Department, seeing a strategic opportunity in this insecurity, knew Australia was 'anxious to see the US military position in the western Pacific strengthened' and it believed the nation could not 'afford to oppose major US policy toward Japan'. ${ }^{115}$ The hope here was that Australia could perhaps be convinced to support US policy towards Japan in return for security assurances. This logic was apparent in the future ANZUS Treaty signed in exchange for Australia's support of a lenient peace treaty with Japan. Australia's standing as a possible ally and, to that end, US support for the Colombo Plan were helped along by the outbreak of the Korean War and Spender's opportunistic offer to send

114 'Doc. 22, Record of the Conversation Between Jessup and Representatives of the British Foreign Office, London, 11 March 1950', in Neil H. Petersen, William Z. Slany, Charles S. Sampson, John P. Glennon and David W. Mabon (eds), Foreign Relations of the United States, 1950, East Asia and the Pacific, Volume VI (Washington, DC: US Government Printing Office, 1976) [hereinafter FRUS 1950]; 'Memorandum, Hodgson (Head of Australian Mission in Japan) to Spender, 20 April 1950', NAA: A1838, 3103/11/161 Part 4.

115 'Doc. 96, Department of State Policy Statement, 21 April 1950', in Petersen et al., FRUS 1950. 
Australian ground troops to Korea. For that matter, the Korean War was also a major factor in closing the dollar gap as US military commitments necessitated increased purchases from the Sterling Area, although this did coincide with increased commercial and technical development in SouthEast Asia. ${ }^{116}$

Australia's postwar strategy for regional engagement was multifaceted and highly opportunistic. Economic development in South-East Asia and the Pacific would preserve the Sterling Area, provide a long-term investment in future markets for Australian exports, promote regional goodwill and stability and revive British influence in the region-all of which were critical in building Australia's capabilities. As the Cold War entered Asia and the United States' strategic outlook expanded to include South-East Asia, the Menzies government was provided with a chance to transform the strategy developed during the Chifley years into a tangible policy. Yet, as the next chapter explores, the shared Cold War outlook of Australia, Britain and the US did not necessarily secure a Commonwealth-US partnership that would safeguard Australia's national interests. 
This text is taken from The Genesis of a Policy: Defining and Defending Australia's National Interest in the Asia-Pacific, 1921-57, by Honae Cuffe, published 2021 by ANU Press, The Australian National University,

Canberra, Australia.

doi.org/10.22459/GP.2021.06 